\title{
Use of paracrine factors from stem cells to treat local radiation burns in rats
}

\section{Andrey Temnov, ${ }^{1-3}$ Tatyana Astrelina, ${ }^{1-3}$ Konstantin Rogov, ${ }^{1-3}$ Boris Moroz, ${ }^{1-3}$ Vladimir Lebedev, ${ }^{1-3}$ Tamara Nasonova, ${ }^{1-3}$ Alla Lyrshchikova, ${ }^{1-3}$ Olga Dobrynina, ${ }^{1-3}$ Yury Deshevoy, ${ }^{1-3}$ Alexander Melerzanov, ${ }^{3}$ Augustinus Bader, ${ }^{4}$ Apurva Mishra, ${ }^{3}$ Shibashish Giri, 4,5 Valeriy Boyarintsev, ${ }^{1-3}$ Alexander Trofimenko, ${ }^{1-3}$ Andrey Bushmanov, ${ }^{1-3}$ Alexander Samoylov ${ }^{1-3}$}

'State Research Center - Burnasyan Federal Medical Biophysical Center of Federal Medical Biological Agency (SRC-FMBC), Moscow, Russia; ${ }^{2}$ Research Institute of Human Morphology, Russian Academy of Medical Science, Moscow, Russia; ${ }^{3}$ Faculty of Biological and Medical Physics. Moscow Institute of Physics and Technology (MIPT), Moscow Region, Russia; ${ }^{4}$ Applied Stem Cell Biology and Cell Technology, Biomedical and Biotechnological Center, Leipzig University, Leipzig, Germany; ${ }^{5}$ Department of Plastic and Hand Surgery, University Hospital Rechts der Isar, Munich Technical University, Munich, Germany

Correspondence: Shibashish Giri Applied Stem Cell Biology and Cell Technology, Biomedical and Biotechnological Center, Leipzig University, Deutscher Platz 5, 04103 Leipzig, Germany

Department of Plastic and Hand Surgery, University Hospital Rechts der Isar, Munich Technical University, Munich, Germany Tel $+4934 \mid 973$ I353

Fax $+4934 \mid 973$ I329

Email Shibashish.giri@bbz.uni-leipzig.de
This article was published in the following Dove Press journal: Stem Cells and Cloning:Advances and Applications

Background: Mesenchymal stem cells based paracrine bioactive factors that deploy their task as an essential mechanism, but their efficiency for skin regeneration still requires clarification. Methods: The mesenchymal stem cell-based paracrine factors were administered by subcutaneous injection of $0.5 \mathrm{~mL}$ peptides (general protein $8 \mathrm{mg} / \mathrm{mL}$ ). These were performed after radiation on different days like the first, third, sixth, eighth, and 10th. To determine the consequences, we performed photography, planimetry, and preclinical test each week after 15 days of radiation. MSC-based peptides were injected into a rat that had radiation burns, and its observation encouraged cell-free therapeutic remedies to regenerate skin. Both control and experimental groups were exposed to 110 Gy of X-rays, which resulted in the formation of localized radiation burns on the skin $\left(S=6 \mathrm{~cm}^{2}\right) 15$ days later. Thirty days after radiation, the wound stabilized (surface of the wound was $S=2.2 \pm 0.2 \mathrm{~cm}^{2}$ ) and fluctuated throughout the course of the pathological process. Results: The wounded area on the skin from the 15 th to the 29 th day after radiation was practically the same in both groups. The wounded area gradually reduced by $6.1 \pm 0.4 \mathrm{~cm}^{2}$ (experimental group) and $5.9 \pm 0.6 \mathrm{~cm}^{2}$ (control group) 15 days after radiation up to $2.2 \pm 0.3 \mathrm{~cm}^{2}$ (in both control and experimental groups) on the 29th day after radiation. However, starting from the 36 th day, there was a constant reduction in the burn area in the experimental group up to $0.2 \pm 0.1 \mathrm{~cm}^{2}$ till the 71 st day after radiation.

Conclusion: In the control group, the area of the lesion ranged from $1.4 \pm 0.6 \mathrm{~cm}^{2}$ on the 50 th day to $1.9 \pm 0.8 \mathrm{~cm}^{2}$ on the 71 st day. During the 57 th to the $71 \mathrm{st}$ day, the difference between the affected area in the experimental and control groups was 1:8. The experimental group has a significantly higher level of skin regeneration and significant decrease in the level of leukocyte infiltration, thereby reducing necrosis.

Keywords: Mesenchymal stem cells, MSC-based paracrine factors, radiation burn, skin regeneration

\section{Introduction}

Severe radiation burns of the skin in most cases are often caused by human errors or accidents. However, up to $95 \%$ of patients undergoing radiation therapy get local radiation burns at varying intensities. ${ }^{1}$ The skin may react to varying degrees (erythema, edema, necrosis, and sclerosis) depending on the type of radiation, dose, and depth of penetration. ${ }^{2}$ Usually, severe radiation burns in a clinical setting are accidental. These burns are either because of overexposure as a result of time or faulty equipment and cause serious complications that require a longer recovery period. It should be noted that despite advances in the treatment methods (including surgical techniques), in case of severe radiation injuries to the skin, the clinical results are not satisfactory. ${ }^{3}$ To reduce the effects of radiation, the use of stem cells as a novel treatment has been

Stem Cells and Cloning:Advances and Applications 20 I8:I I 69-76 (c) 2018 Temnov et al. This work is published and licensed by Dove Medical Press Limited. The full terms of this license are available at https://www.dovepress.com/terms. (c) By Nhp and incorporate the Creative Commons Attribution - Non Commercial (unported, v3.0) License (http://creativecommons.org/licenses/by-nd/3.0/). By accessing the work you hereby accept the Terms. Non-commercial uses of the work are permitted without any further permission from Dove Medical Press Limited, provided the work is properly attributed. For permission for commercial use of this work, please see paragraphs 4.2 and 5 of our Terms (https://www.dovepress.com/terms.php). 
suggested in scientific literature for a long period of time..$^{4-9}$ Many researchers believe that the clinical effects of stem cells in the treatment of acute and chronic trauma of internal organs are not related to the cells themselves, but the paracrine factors that are secreted by them in the intercellular space. ${ }^{10}$ As has been shown in previous experiments, paracrine factors secreted by cultured stem cells are effective in treating acute chemical and thermal burns of the skin and mucous membranes. ${ }^{11,12}$ Keeping in adherence to this, the aim of our experiment was to study the effect/impact of paracrine factors taken from stem cells from the bone marrow of rats in the treatment of local radiation burns.

The paracrine bioactive factors are produced by mesenchymal stem cells (MSCs) that deploy their task by paracrine factors as an essential mechanism, but their efficiency to regenerate still requires clarification. The demonstrations were executed on 16 male adult Wistar rats in radiation burn injury models. Once the experiment crossed 80 days of irradiation, the animals were removed and the ulceration was removed including healthy tissue. A morphometric evaluation was done with the samples to understand the maturity ratio of the granulating tissue. It was essential to assess the cell contents and so the thin inflamed necrotic membrane, middle, and innermost layers of the maturing granulating tissue and cells were evaluated. In the histological sections of the control animals, hyperplasia of the regenerating epidermis can be seen on the edge of the ulcer with symptoms of keratinization and acanthosis. The surface of the ulcer showed granulated tissue with abundant polymorphonuclear leukocytes (PMLs) and additional vessels with thickened and hyalinized walls. Their lumen also exhibited an accumulation of PML. Maturing fibrous tissue deep within the ulcer showed mild infiltration by lymphocytes. The histological sections obtained from the experimental group showed complete epidermization deepseated in the ulcer. It was covered by a layer of maturing keratinized stratified squamous epithelium and mature fibrous tissue with slight diffusion of infiltration by lymphocytes. Morphometry table shows that the use of paracrine factors obtained from stem cells dramatically increases the maturation of granulated tissue in the bottom and the peripheral part of the wound. The MSC-based paracrine factors renew the process of reparative regeneration in intact tissues.

\section{Materials and methods}

All the experimental procedures were approved by the Committee of Animal Care, Department of Biotechnology, Moscow Institute of Physics and Technology, g. Dolgoprudnyy, Russia. The investigation conforms to the Guidelines for the Care and Use of Laboratory Animals published by the US
National Institutes of Health (NIH Publication No 85-23, revised 1985). The experiments were performed on 16 male adult rats belonging to the breed Wistar weighing between 235 and $315 \mathrm{~g}(\mathrm{M} \pm \mathrm{m}, 283.1 \pm 12.0 \mathrm{~g}$ experimental group and $283 \pm 8.6 \mathrm{~g}$ control group). The animals were kept in humane conditions including a standard diet and free access to drinking water. The living conditions and experimental procedures adhered to the general rules involved with experimental animals. The plan and execution of the experiment was approved and controlled by the Ethics Committee of the Institute. All manipulations to the animals were carried out after administering anesthesia (combination of Zoletil and Romitar). Rats were locally irradiated using the instillation ЛНК-268 (РАП 100-10) with a dose of 110 Gy at the rate of $21.4 \mathrm{~Gy} / \mathrm{min}$, voltage $30 \mathrm{kV}$, current $6.1 \mathrm{~mA}$, filter $0.1 \mathrm{~mm}$ AI, and an exposure of 312 seconds. The rats were fixed on a specialized table on their abdomen (face down). The area of the irradiation field in the pre-iliac-lumbar region of the back was 8.2 and $8.5 \mathrm{~cm}^{2}$ and the fur from the region was removed.

\section{Isolating stem cells from the bone marrow}

The MSCs were isolated from the bone marrow located in the hip bone under general anesthesia. The bone marrow mononuclear cell fraction was isolated by creating a density gradient using standard solution of lymphocyte-H (Cedarlane, Hornby, Ontario, Canada). After obtaining the suspension, the mononuclear cells were plated on to a Petri dish and cultured in DMEM and 10\% FBS. To prove that the cells obtained had properties of MSC, they underwent osteocyte, chondrocyte, and adipocyte differentiation following standard protocol. ${ }^{13}$

\section{Obtaining peptides}

After the cells had formed a monolayer, the medium was changed, and within 3 days the conditioned medium was collected. The conditioned medium was filtered using a filter with a diameter of $0.22 \mu \mathrm{m}$.

\section{Scheme of administering the paracrine factors}

The peptides were administered in the form of an injection subcutaneously $0.5 \mathrm{~mL}$ (general protein $8 \mathrm{mg} / \mathrm{mL}$ ) on the first, third, sixth, eighth, and tenth day after radiation.

\section{Evaluating results}

Photography, planimetry, and clinical assessment were carried out every week starting 15 days after radiation.

The area of skin damaged by radiation was calculated using the program DraftSight $20017 \times 64$. The severity of the 
pathological process was visually evaluated and assigned numerically (Table 1).

\section{Histology}

The animals were taken out of experiment 80 days after the irradiation. The ulcerative lesion was excised in its entirety along with healthy tissue and fixed with $10 \%$ buffered formalin. The measurement of the area and the grade of severity of the pathological process are presented in the tables and figures. Histological morphometry of the samples was conducted to assess the level of maturation in the granulating tissue. Prior to the analysis, the cell contents of the superficial (under the thin inflamed necrotic membrane), middle, and inner most layer of the maturing granulating tissue were evaluated.

The data were quantitatively analyzed with the help of Image Tool for Windows, v. 3.0 ("UTHSCSA", USA). After calibrating the normal distribution, the average arithmetic value (M) and the SD of the arithmetic mean (m) was calculated. Verification of the reliability in differences was based on student criterion $(t)$. The mathematical calculations of quantitative data pertaining to histological preparations were performed using nonparametric statistics with a calculated median and interpercentile range. The comparison of the groups was undertaken with the help of multiple comparisons Kruskal-Wallis (packet of statistical programs Statistica-8; "StatSoft").

\section{Results}

Both control and experimental groups were exposed to 110 Gy of X-rays, which resulted in the formation of localized radiation burns on the skin $\left(S=6 \mathrm{~cm}^{2}\right) 15$ days later. Thirty days after radiation, the wound stabilized (surface of the wound was $S=2.2 \pm 0.2 \mathrm{~cm}^{2}$ ) and fluctuated throughout the course of the pathological process.

As seen in Figure 1A, the wounded area on the skin from the 15 th to the 29 th day after radiation was practically the same in both groups. The wounded area gradually reduced by $6.1 \pm 0.4 \mathrm{~cm}^{2}$ (experimental group) and $5.9 \pm 0.6 \mathrm{~cm}^{2}$ (control group) 15 days after radiation up to $2.2 \pm 0.3 \mathrm{~cm}^{2}$ (in both control and experimental groups) on the 29 th day after radiation. However, starting from the 36th day, there was a constant reduction in the burn area in the experimental group up to $0.2 \pm 0.1 \mathrm{~cm}^{2}$ till the $71 \mathrm{st}$ day after radiation. In the control group, the area of the lesion ranged from $1.4 \pm 0.6 \mathrm{~cm}^{2}$ on the 50 th day to $1.9 \pm 0.8 \mathrm{~cm}^{2}$ on the $71 \mathrm{st}$ day. During the 57 th to 71 st day, the difference between the affected area in the experimental and control groups was 1:8.

Judging by clinical manifestations, the experimental group started showing significant differences from the control group 21 days after radiation (Figure 1B). Starting from the 36 th day after radiation to the end of radiation, the difference between the clinical manifestations (represented as grades) in the control and experimental groups was statistically significant $(P<0.05)$. Visually the scabs in the experimental group of rats were thinner and superficial compared with the control group. On the 43rd day after irradiation, the pathological process in one of eight rats $(12.5 \%)$ in the experimental group had terminated with the formation of an atrophied scar. On the 71 st day in the experimental group, four rats $(50 \%)$ had shown atrophied scars, and in the control group, only one $(12.5 \%)$. Furthermore, during this time period five of eight

Table I Grading scale assessing the skin's reaction to a radiation dose of I I0 Gy

\begin{tabular}{|l|l|l|}
\hline Phase of damage up to $\sim \mathbf{4 0}$ days & Grade & Phase of recovery \\
\hline No observable changes & 0 & Atrophic scarring \\
\hline Hyperemia (+l-), impaired fur growth & 0.15 & \\
\hline Hyperemia (+l-), hyperpigmentation, peeling & 0.25 & \\
\hline Hyperemia, hyperpigmentation & 0.5 & Scarring, light crust \\
\hline Dry dermatitis & $\mathrm{I}$ & Scarring, crust on $\sim 10 \%-20 \%$ \\
\hline Moist dermatitis & 1.5 & Scarring, crust on $\sim 30 \%-50 \%$ \\
\hline Thin dry scab & 2 & Scarring, flat scab \\
\hline Dense dry scab & 2.5 & Dense scab in an area $<70 \%$ \\
\hline Dense scab, serous exudates & 3 & Dense scabs in an area $<50 \%$ \\
\hline Flat dry scab & 3.5 & \\
\hline Flat dry scab, serous exudates & 4 & Thin, fibrin, serous exudates \\
\hline Rough, heterogeneous scab, tightly adhered, superficial & 4.5 & Thin superficial membrane, moist, blood \\
\hline Rough heterogeneous scab, superficial serous exudate & 5 & Deep wound, thin and flat scab \\
\hline Rough, dense dry scab, deep & 5.5 & Dense dry, deep \\
\hline Rough, deep scab, purulent exudate or blood & 6 & \\
\hline
\end{tabular}


A
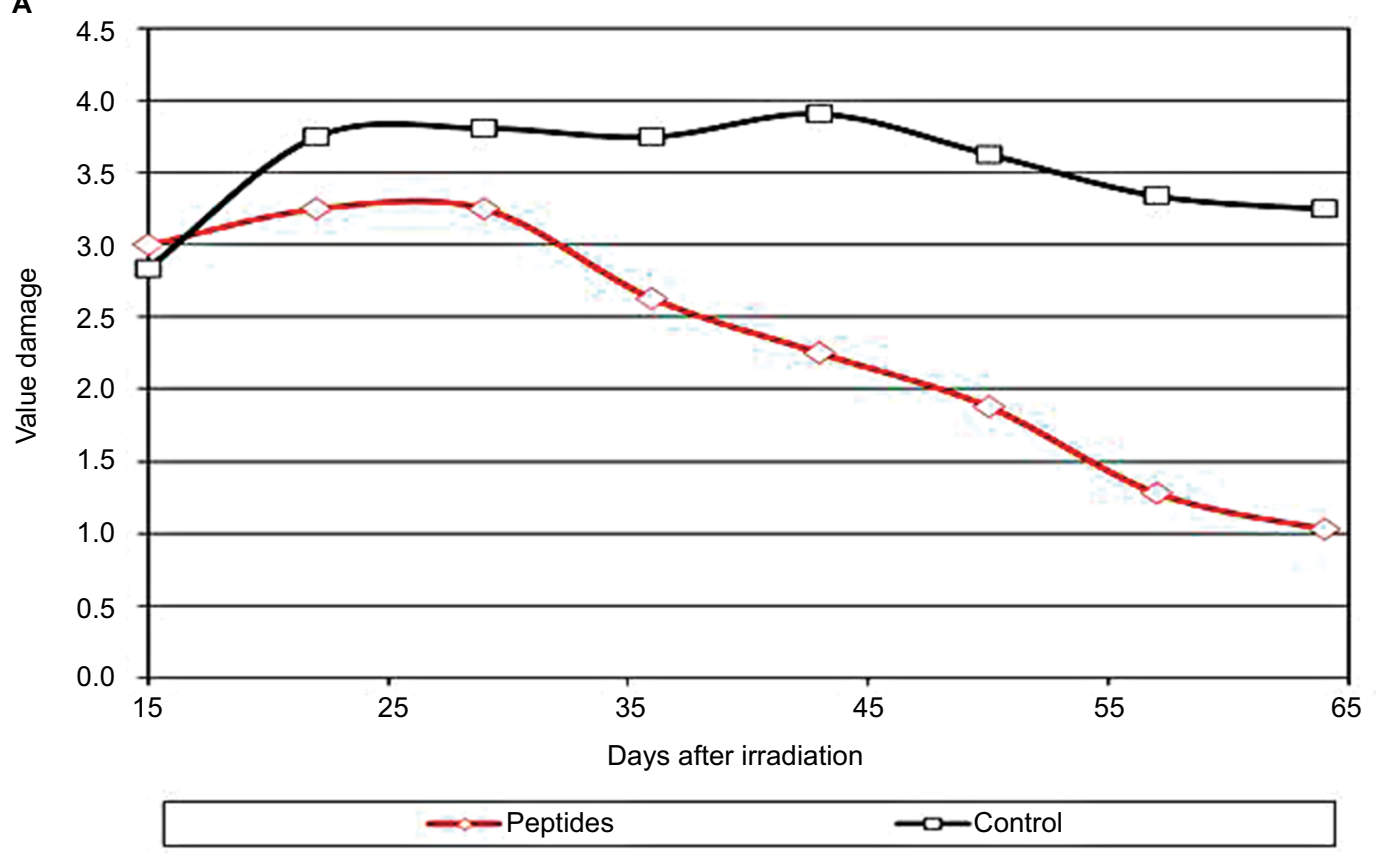

B

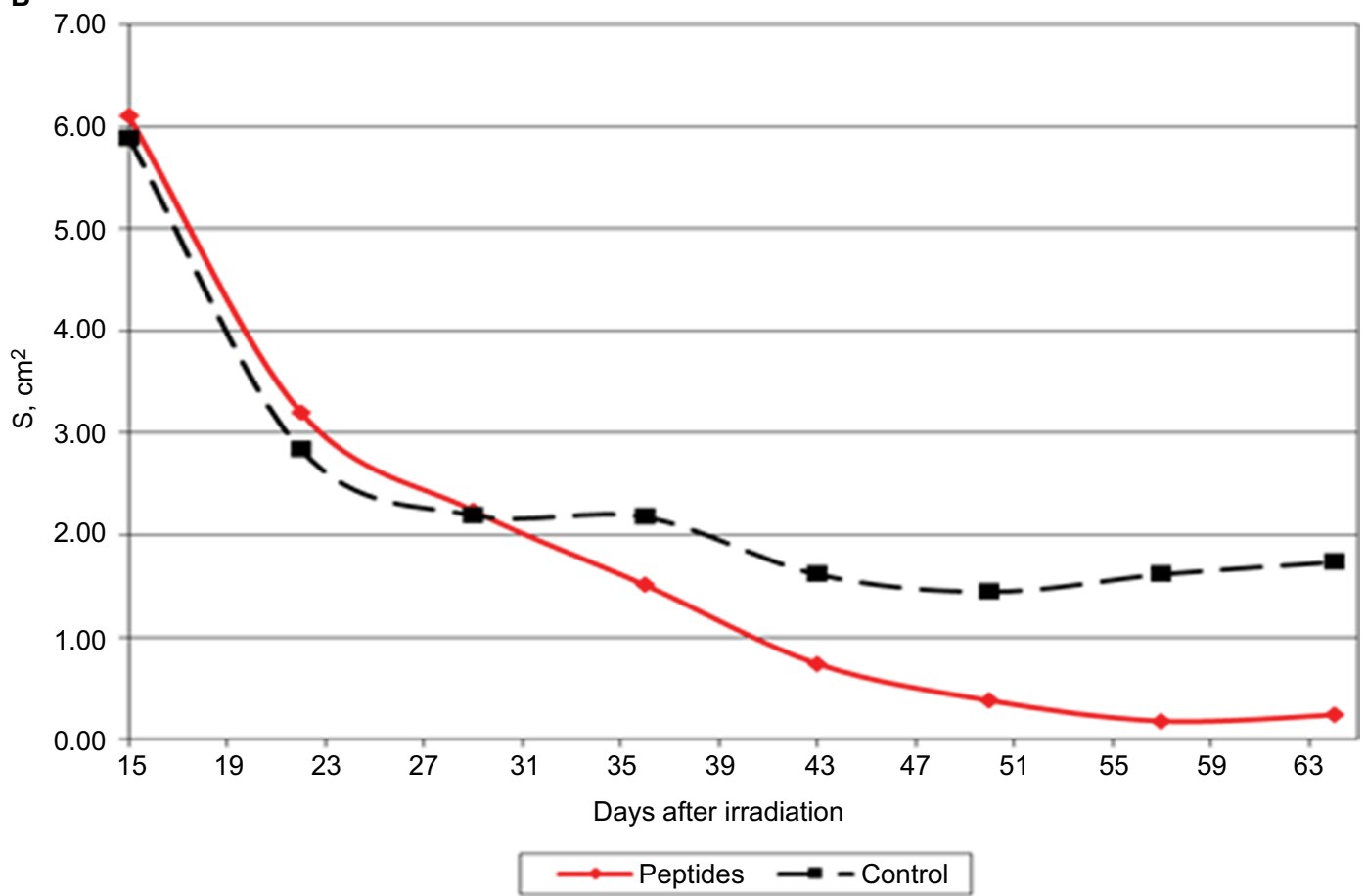

Figure I Dynamics of healing acute radiation injury in rats.

Notes: (A) Area of injury; (B) severity of clinical process. Severity of the pathological process in the rats was evaluated using a grading scale (Figure IB).

rats in the control group exhibited deep and extensive ulcers ranging from 2 to $6 \mathrm{~cm}^{2}$, and in the experimental group, only two rats were left with light superficial scars with an area of 1.0 and $0.6 \mathrm{~cm}^{2}$.

According to clinical manifestations, the experimental groups already began to significantly differ from the control group by the 21 st day (Figure 1). The scabs in the experimental group were visually thinner and superficial in comparison with the control group.

In the histological sections (Figure 2) of the control animals, hyperplasia of the regenerating epidermis can be seen on the edge of the ulcer with symptoms of keratinization and acanthosis. The surface of the ulcer showed granulated tissue with abundant PML and additional vessels with thickened and 

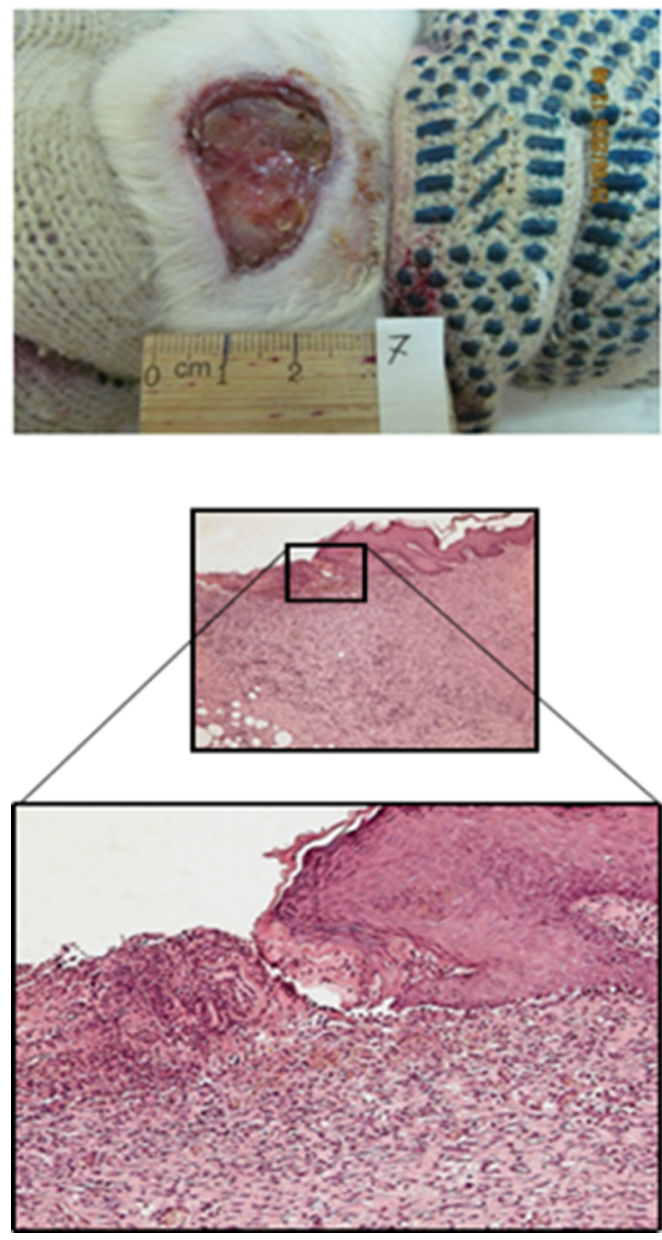

Figure 2 Zone of lesion on the 7 Ist day.

Notes: Dyed with H\&E stain. Magnification of $200 \times$ (A) and $100 \times$ (B).

hyalinized walls. Their lumen also exhibited an accumulation of PML. Maturing fibrous tissue deep within the ulcer showed mild infiltration by lymphocytes.

The histological sections obtained from the experimental group showed complete epidermization deep seated in the ulcer. It was covered by a layer of maturing keratinized stratified squamous epithelium and mature fibrous tissue with slight diffusion of infiltration by lymphocytes.

The grading scale (Table 2) of the histological results showed that the experimental group has a significantly higher level of regeneration with respect to skin-related wounds.

The experiment showed significant decrease in the level of leukocyte infiltration in the dermis of subcutaneous cells, thereby reducing necrosis.

Morphometry (Table 3) shows that the use of paracrine factors obtained from steam cells dramatically increases the maturation of granulated tissue in the bottom and the
B Experimental group
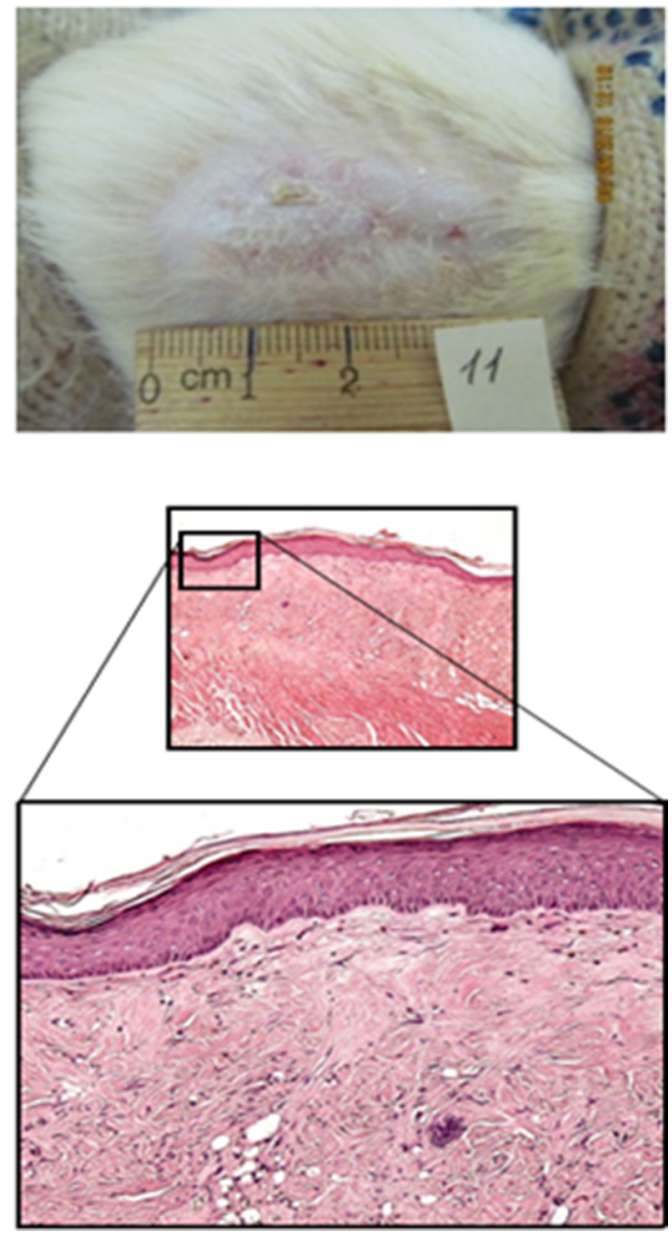

peripheral part of the wound. This in turn renews the process of reparative regeneration in intact tissues.

\section{Discussion}

The outcome of local radiation injuries of the skin (LRIS) is dependent on the radiation dose, area of injury, and the reaction of the organism itself. High doses of radiation cause the dysregulation of pro- and anti-inflammatory systems and as a rule, acute reactions turn to chronic inflammation.

Treating such chronic injuries requires surgical intervention with the excision of pathological tissues. This invasion shifts the process back to chronic inflammation, thereby ending the proliferative phase and overall repair of the tissue.

One of the possible causes for such a "chronic" process can be the dysfunction of regulatory cells (primarily immune cells), which are responsible for local inflammatory 
Table 2 Quantitative grading of the level of inflammatory responses ( 80 days after exposure)

\begin{tabular}{|c|c|c|c|c|c|}
\hline & & & & Control & Peptides \\
\hline \multirow[t]{8}{*}{ Epidermis } & Thickening of the epidermis & Absent & 3 & \multirow[t]{4}{*}{0.75} & \multirow[t]{4}{*}{1.75} \\
\hline & & Weak & 2 & & \\
\hline & & Moderate & $\mathrm{I}$ & & \\
\hline & & Significant & 0 & & \\
\hline & Stratification of keratinocytes & Preserved & $\mathrm{I}$ & \multirow[t]{2}{*}{0} & \multirow[t]{2}{*}{0.75} \\
\hline & & Impaired & 0 & & \\
\hline & Necrosis of the epidermis & Absent & $\mathrm{I}$ & \multirow[t]{2}{*}{0} & \multirow[t]{2}{*}{0.5} \\
\hline & & Present & 0 & & \\
\hline \multirow[t]{6}{*}{ Dermis } & \multirow[t]{4}{*}{ Infiltration by leukocytes } & Absent & 3 & \multirow[t]{4}{*}{0} & \multirow[t]{4}{*}{$2.75^{a}$} \\
\hline & & Weak & 2 & & \\
\hline & & Moderate & 1 & & \\
\hline & & Significant & 0 & & \\
\hline & \multirow[t]{2}{*}{ Necrosis of the dermis } & Absent & $\mathrm{I}$ & \multirow[t]{2}{*}{0} & \multirow[t]{2}{*}{0.75} \\
\hline & & Present & 0 & & \\
\hline \multirow[t]{6}{*}{ Subcutaneous fat } & \multirow[t]{4}{*}{ Infiltration by leukocytes } & Absent & 3 & \multirow[t]{4}{*}{0} & \multirow[t]{4}{*}{$2.75^{a}$} \\
\hline & & Weak & 2 & & \\
\hline & & Moderate & $\mathrm{I}$ & & \\
\hline & & Significant & 0 & & \\
\hline & \multirow{2}{*}{$\begin{array}{l}\text { Necrosis of subcutaneous tissue and } \\
\text { surrounding tissue }\end{array}$} & Absent & $\mathrm{I}$ & \multirow[t]{2}{*}{0.25} & \multirow[t]{2}{*}{1.0} \\
\hline & & Present & 0 & & \\
\hline \multirow[t]{2}{*}{ Regeneration } & Absent & 1 & & \multirow[t]{2}{*}{0.25} & \multirow[t]{2}{*}{1.0} \\
\hline & Present & 0 & & & \\
\hline \multicolumn{4}{|l|}{ SUM $\Sigma$} & 1.25 & $11.25^{\mathrm{a}}$ \\
\hline
\end{tabular}

Notes: ${ }^{a}<<0.05$ with respect to the control.

Table 3 Morphometry of the cell population in the skin wound ( 80 days after exposure)

\begin{tabular}{|c|c|c|c|c|c|c|}
\hline Specimen & Quantity & $\begin{array}{l}\text { Deep layer of } \\
\text { the granulated } \\
\text { tissues }\end{array}$ & $\begin{array}{l}\text { Middle layer of } \\
\text { the granulated } \\
\text { tissues }\end{array}$ & $\begin{array}{l}\text { Superficial layer } \\
\text { of the granulated } \\
\text { tissues }\end{array}$ & Mean & $\begin{array}{l}\text { Fibroblast/ } \\
\text { cells }\end{array}$ \\
\hline \multirow[t]{2}{*}{ Control I } & Cells & 606 & 444 & 284 & 444.7 & \multirow[t]{2}{*}{0.47} \\
\hline & Fibroblast & 195 & 216 & 213 & 208 & \\
\hline \multirow[t]{2}{*}{ Control 2} & Cells & 504 & 316 & 316 & 378.6 & \multirow[t]{2}{*}{0.48} \\
\hline & Fibroblast & 166 & 178 & 197 & 180.1 & \\
\hline \multirow[t]{2}{*}{ Control 3} & Cells & 647 & 378 & 152 & 392.6 & \multirow[t]{2}{*}{0.42} \\
\hline & Fibroblast & 181 & 198 & 113 & 164 & \\
\hline \multirow[t]{2}{*}{ Control 4} & Cells & 518 & 321 & 248 & 362.4 & \multirow[t]{2}{*}{0.40} \\
\hline & Fibroblast & 122 & 147 & 166 & 144.8 & \\
\hline \multirow[t]{2}{*}{ Peptides I } & Cells & 109 & 121 & Superficial & $\mathrm{II} 4.8$ & \multirow[t]{2}{*}{0.71} \\
\hline & Fibroblast & 74 & 88 & epithelialization & 81 & \\
\hline \multirow[t]{2}{*}{ Peptides 2} & Cells & 123 & 92 & Superficial & 107.3 & \multirow[t]{2}{*}{0.65} \\
\hline & Fibroblast & 78 & 62 & epithelialization & 70.2 & \\
\hline \multirow[t]{2}{*}{ Peptides 3} & Cells & 290 & 102 & 102 & 164.8 & \multirow[t]{2}{*}{0.43} \\
\hline & Fibroblast & 96 & 41 & 75 & 70.8 & \\
\hline \multirow[t]{2}{*}{ Peptides 4} & Cells & 136 & $13 \mid$ & Superficial & 133.2 & \multirow[t]{2}{*}{0.67} \\
\hline & Fibroblast & 91 & 87 & epithelialization & 89.2 & \\
\hline \multirow[t]{2}{*}{ Peptides 5} & Cells & 140 & 177 & Superficial & 158.7 & \multirow[t]{2}{*}{0.50} \\
\hline & Fibroblast & 75 & 82 & epithelialization & 78.7 & \\
\hline
\end{tabular}

responses. If this theory holds true, then the addition of new and functionally active cells in the center of such lesions could potentially restore the regulation of local inflammatory responses.
Apparently, the properties of MSC include the selection of regulatory mediators and peptides, which further determines their effectiveness in the treatment of LRIS. It is to be expected that the paracrine function of MSCs is the basis of 
its clinical effect. This opinion is shared by most researchers using cells in the treatment of LRIS. ${ }^{10}$

Majority of them have highlighted the anti-inflammatory and immunoregulatory effect tied with the mediators secreted by cells. ${ }^{14}$

It must be mentioned that the use of functionally active autoregulatory cells leads to a pronounced clinical effect observed in not only radiation injuries but in most acute traumas. ${ }^{15}$

The question still stands, which source of MSC should be used to safely and effectively treat acute radiation injuries.

If it was to be assumed that the prime time to transplant cells in the event of acute injuries is early (hours within the first day of exposure), then doctors simply will not be able to isolate and prepare the required quantity of cells from the bone marrow. An alternative can be the use of stromal vascular fraction (SVF). However, the feasibility of performing liposuction on patients with acute post-traumatic stress requires further research. Additionally, the isolation of the SVF can only be carried out at a hospital by an experienced professional.

The use of allogenic MSCs also has its limitations, like the risk of infections or the reactivation of viral infections. ${ }^{16}$ Next, the introduction of genetically alien material against a background of stress immunodeficiency can lead to the development of oncology. ${ }^{17}$

Although human MSC-based bioactive factors are not clearly identified or determined, the therapeutic effects of stem cell transplantation depend on the production of paracrine bioactive factor. The strategy has been a promising cell-free therapeutic method for neovascularization in ischemic diseases. ${ }^{18}$ Stem cell-based paracrine factors promote cardiac repair and regeneration reviewed elsewhere. ${ }^{19}$ Further research is required to identify the specific paracrine factors that are more essential for regeneration of cell/tissue/organs.

The current aim of the study was to evaluate the viability of creating a medicinal product derived from MSCs containing paracrine factors. These factors in turn display anti-inflammatory and immunomodulatory effects. This medicinal product will enable the provision of first aid even outside clinics to reduce the degree of inflammation. This will further create conditions for conducting a full-scale cell therapy using autologous stem cells.

Our research has shown that animals subjected to very high doses of radiation (110 Gy) develop an acute inflammatory response. A fixed reduction in the area throughout the process of injury was not observed upon the use of paracrine factors from stem cells. This most likely indicates that these factors do not have a protective effect and they cannot save the cells from permanent damage. However, during the autopsy, it was noted that none of the animals in the experimental group had cicatricial adhesions. The damage was limited to the dermal layer. In the control group, inflammation besides the skin had spread to the fascia, muscular layer of the abdominal wall, and occasionally, in the loops of the intestine. It would seem that our product reduces inflammation at the alteration stage and aids in the correct exchange of inflammatory phases.

The obtained results help us evaluate the medicinal product, the paracrine factors it contains, and future perspectives in creating novel medicinal products for treating LSIR.

\section{Acknowledgment}

The study was supported by the Russian Foundation for Basic Research (RFBR grants 17-07-00439).

\section{Disclosure}

The authors report no conflicts of interest in this work.

\section{References}

1. Porock D, Nikoletti S, Kristjanson L. Management of radiation skin reactions: literature review and clinical application. Plast Surg Nurs. 1999;19(4):185-192.

2. Hopewell JW. The skin: its structure and response to ionizing radiation. Int J Radiat Biol. 1990;57(4):751-773.

3. Peter RU. Cutaneous radiation syndrome in multiorgan failure. $\mathrm{Br} J$ Radiol Suppl. 2005;27:180-184

4. Hill RP, Rodemann HP, Hendry JH, Roberts SA, Anscher MS. Normal tissue radiobiology: from the laboratory to the clinic. Int J Radiat Oncol Biol Phys. 2001;49(2):353-365.

5. Badiavas EV, Abedi M, Butmarc J, Falanga V, Quesenberry P. Participation of bone marrow derived cells in cutaneous wound healing. $J$ Cell Physiol. 2003;196(2):245-250.

6. Chapel A, Bertho JM, Bensidhoum M, et al. Mesenchymal stem cells home to injured tissues when co-infused with hematopoietic cells to treat a radiation-induced multi-organ failure syndrome. J Gene Med. 2003;5(12):1028-1038.

7. Epperly MW, Guo H, Gretton JE, Greenberger JS. Bone marrow origin of myofibroblasts in irradiation pulmonary fibrosis. Am J Respir Cell Mol Biol. 2003;29(2):213-224.

8. Dantzer D, Ferguson P, Hill RP, et al. Effect of radiation and cell implantation on wound healing in a rat model. J Surg Oncol.2003;83(3):185-190.

9. Satoh H, Kishi K, Tanaka T, et al. Transplanted mesenchymal stem cells are effective for skin regeneration in acute cutaneous wounds. Cell Transplant. 2004;13(4):405-412.

10. Khubutiya MS, Vagabov AV, Temnov AA, Sklifas AN. Paracrine mechanisms of proliferative, anti-apoptotic and anti-inflammatory effects of mesenchymal stromal cells in models of acute organ injury. Cytotherapy. 2014;16(5):579-585.

11. Temnov AA, Volkova AG, Melerzanov AV, Novoselov VI. Effect of conditioned medium from mesenchymal stem cells on regeneration of endothelium at $\mathrm{HCl}$-induced damage trachea in rats. Patol Fiziol Eksp Ter. 2017;61(2):28-36.

12. Temnov AA, Vagabov AV, Sklifas AN, Novoselov VI, Belyi YA. The role of mesenchymal stromal cells in the repair of acute organ injury. Chapter 35. In: Atkinson K, editor. The Biology and Therapeutic Application of Mesenchymal Cells. Hoboken: John Wiley \& Sons; 2017:496-523. 
13. Yagi H, Soto-Gutierrez A, Navarro-Alvarez N, et al. Reactive bone marrow stromal cells attenuate systemic inflammation via sTNFR1. Mol Ther. 2010;18(10):1857-1864.

14. Börger V, Bremer M, Ferrer-Tur R, et al. Mesenchymal stem/stromal cell-derived extracellular vesicles and their potential as novel immunomodulatory therapeutic agents. Int J Mol Sci. 2017;18(7): 1450 .

15. Temnov AA, Shumakov VI, Gureev SV, Onishchenko NA. Improvement of myocardial remodelling and functioning in patients undergoing surgical treatment of chronic cardiac insufficiency by two-staged elevation of the immunoregulatory reserve of autological bone marrow cells and their intramyocardial application. Vestn Ross Akad Med Nauk. 2008;1(1):3-9.
16. Sundin M, Orvell C, Rasmusson I, Sundberg B, Ringdén O, Le Blanc $\mathrm{K}$. Mesenchymal stem cells are susceptible to human herpesviruses, but viral DNA cannot be detected in the healthy seropositive individual. Bone Marrow Transplant. 2006;37(11):1051-1059.

17. Amariglio N, Hirshberg A, Scheithauer BW, et al. Donor-derived brain tumor following neural stem cell transplantation in an ataxia telangiectasia patient. PLoS Med. 2009;6(2):e1000029.

18. Kwon HM, Hur SM, Park KY, et al. Multiple paracrine factors secreted by mesenchymal stem cells contribute to angiogenesis. Vascul Pharmacol. 2014;63(1):19-28.

19. Hodgkinson CP, Bareja A, Gomez JA, Dzau VJ. Emerging concepts in paracrine mechanisms in regenerative cardiovascular medicine and biology. Circ Res. 2016;118(1):95-1078.

\section{Publish your work in this journal}

Stem Cells and Cloning: Advances and Applications is an international, peer-reviewed, open access journal. Areas of interest in stem cell research include: Embryonic cell stems; Adult stem cells; Blastocysts; Cordblood stem cells; Stem cell transformation and culture; Therapeutic cloning; Umbilical cord blood and bone marrow cells; Laboratory, animal and human therapeutic studies; Philosophical and ethical issues related to stem cell research. This journal is indexed on CAS. The manuscript management system is completely online and includes a quick and fair peer-review system. Visit http://www.dovepress.com/ testimonials.php to read real quotes from published authors.. 